\title{
Characterization, in vitro cytotoxic and antibacterial exploitation of green synthesized freshwater cyanobacterial silver nanoparticles
}

\author{
Guna Swetha Kuraganti, Sujatha Edla*, Thrimothy Dasari, Mamatha Reddy \\ Department of Microbiology, Kakatiya University, Hanamkonda, India.
}

\begin{tabular}{|c|c|}
\hline ARTICLE INFO & ABSTRACT \\
\hline $\begin{array}{l}\text { Received on: } 18 / 03 / 2020 \\
\text { Accepted on: } 17 / 07 / 2020 \\
\text { Available online: } 05 / 09 / 2020\end{array}$ & $\begin{array}{l}\text { Cyanobacteria-mediated silver nanoparticles synthesis approach has proven to be more efficient and eco-friendly } \\
\text { in achieving biomedical applications compared to physical and chemical prototypes. In the present work, the silver } \\
\text { nanoparticles were successfully synthesized by cell-free extract of freshwater cyanobacteria, i.e., Chroococcus turgidus } \\
\text { and Characium typicum. The cyanobacterial silver nanoparticles (CSNPs) were characterized by UV-Vis spectroscopy, }\end{array}$ \\
\hline $\begin{array}{l}\text { Key words: } \\
\text { Freshwater cyanobacteria, } \\
\text { silver nanoparticles, } \\
\text { characterization, } \\
\text { antimicrobial activity, } \\
\text { cytotoxic activity. }\end{array}$ & $\begin{array}{l}\text { scanning electron microscopy (SEM), transmission electron microscopy (TEM), and Fourier transform infrared (FTIR) } \\
\text { analysis and were further tested for antibacterial and cytotoxic efficiency. The synthesis of CSNPs was confirmed through } \\
\text { visible color change and shift of peaks at } 430-445 \mathrm{~nm} \text { by the UV-Vis spectroscopy. The size of CSNPs was between } \\
22 \text { and } 34 \mathrm{~nm} \text { and oval-shaped which were confirmed by SEM and TEM analyses. The FTIR spectra showed a new } \\
\text { peak at the range of } 3,400-3,460 \mathrm{~cm}^{-1} \text { compared to control, confirming the reduction of silver nitrate. Furthermore, the } \\
\text { antibacterial activity of CSNPs showed highest zone of inhibition with } 6.9,4.0,2.0 \text {, and } 3.0 \mathrm{~mm} \text { against Salmonella } \\
\text { paratyphi, Escherichia coli, Klebsiella pneumonia, and Staphylococus aureus, respectively, whereas in vitro cytotoxic } \\
\text { activity of C. typicum and C. turgidus silver nanoparticles showed remarkable IC } \text { F }_{50} \text { values with } 43.3 \text { and } 40.9 \mathrm{ug} / \mathrm{ml} \\
\text { against MCF-7 breast cancer cell line and } 20.8 \text { and } 55.7 \mathrm{ug} / \mathrm{ml} \text { against HepG2 cancer cell, simultaneously. }\end{array}$ \\
\hline
\end{tabular}

\section{INTRODUCTION}

Nanoscience is an emerging field of nanobiotechnology, utilizing nanobased systems for various biomedical applications. The nanoparticles generally lie in the range of $10^{-9} \mathrm{~nm}$ with dimensions of 1-100 nm (Sharma et al., 2016). Consequently, nanoparticles exhibit therapeutic properties because of their high surface volume, strong binding affinity, and their ability to easily diffuse into the cell (Sun et al., 2014). Among other nanoparticles, silver nanoparticles have prudent specific conductivity and stability with unique therapeutic, antibacterial, and catalytic properties which makes them important in nanooncology and in the diagnosis and treatment of cancer through nanodevices and therapeutic agents (Husain et al., 2015). The synthesis of nanoparticles through physical and chemical processes consumes extreme

"Corresponding Author

Sujatha Edla, Department of Microbiology, Kakatiya University, Hanamkonda, India.E-mail:sujathaedla_1973@ kakatiya.ac.in energy, pollutes the environment, produces toxic chemicals that stick to the surface of particles, and which have inimical effects in medical applications (Nadagouda and Varma, 2008). Green synthesis of nanoparticles is convenient over physical and chemical methods of nanoparticle synthesis, since biologically synthesized nanoparticles are more eco-friendly and energy efficient for the synthesis of inorganic nanoparticles (Jeffryes et al., 2015; Mittal et al., 2013) and economically feasible compared to physical and chemical synthesis.

Green synthesis of nanoparticles is generally carried out by the living forms of bacteria, fungi, viruses, plant extracts, plant parts, algae, yeast, and cyanobacteria (Keskin et al., 2016; Kharissova et al., 2013; Pirtarighat et al., 2019; Swaminathanályer, 2013). Among the biological systems, cyanobacteria are preferable since they can be easily cultivated with a high growth rate and they reduce silver ions expeditiously (Roychoudhury et al., 2016). Cyanobacteria are one of the prominent bio-factories that produce a wide range of bioactive compounds, i.e., secondary metabolites, like minerals, lipids, proteins, polysaccharides, carbohydrates, carotenoids, and 
vitamins, and number of other auxiliary metabolites with a wide scope of biological activities and applications (Kim, 2011). The bioactive compounds produced by cyanobacteria are chemically diverse sources of new pharmaceutical compounds that exhibit a wide range of biomedical applications. These metabolites are cytotoxic metabolites, antibacterial and antifungal metabolites, protein inhibitors, alkaloids, peptides, and terpenoids (Chlipala et al., 2011).

Freshwater cyanobacteria are able to synthesize nanoparticles, intracellularly as well as extracellularly. The functional groups like hydroxyl, amino, and carboxyl are generally responsible for capping and act as reducing agents. The size of the nanoparticle differs from intracellularly and extracellularly synthesized particles, i.e., $10 \mathrm{~nm}$ to $100-200$ $\mathrm{nm}$, respectively. The organic compounds like proteins attribute to the extracellular synthesis of silver nanoparticles (Sharma et al., 2016). The silver nanoparticles that are extracellularly synthesized are spherical in size and are between 100 and $200 \mathrm{~nm}$ (Ali et al., 2011). The size, number, and shape of the nanoparticle are directly proportional to the concentration and time period of exposure to silver ions (Tsibakhashvili et al., 2011)

The silver nanoparticles synthesized from freshwater cyanobacteria evince the secretion of bioactive compounds, and when combined with AgNP's (silver nanoparticles) they show a wide variety of biomedical applications, including cytotoxic activity, which is exploited in cancer treatment, one of the deadliest diseases in the world. In our study, silver nanoparticles are synthesized extracellularly from freshwater cyanobacteria, such as Chroococcus turgidus and Characium typicum, and are characterized by scanning electron microscopy (SEM), transmission electron microscopy (TEM), and Fourier transform infrared (FTIR) spectroscopy. The cyanobacterial silver nanoparticles (CSNPs) were investigated for antibacterial and cytotoxic activities against human MCF-7 breast cancer cell lines and HepG2 cell line.

\section{MATERIALS AND METHODS}

\section{Isolation and cultivation of cyanobacterial cultures}

Silver nanoparticles were synthesized from two cyanobacterial strains, C. turgidus and C. typicum, isolated from the freshwater habitats in Telangana. The cultures were maintained through a common subculturing method in the BG11 medium in laboratory conditions at $25^{\circ} \mathrm{C}$ under continuous cool white fluorescent light. The isolates were identified based on their morphological characters and molecular sequencing (AL-Sultan, 2017).

\section{Biosynthesis of Ag-NPs by cyanobacterial cultures}

Preparation of cell-free extract for nanoparticle biosynthesis

The cyanobacterial cultures were grown in the BG11 medium and harvesting was conducted by centrifuging at 5,000 rpm for 10 minutes (REMI R-8C laboratory centrifugation) at $15^{\circ} \mathrm{C}$ and washed thoroughly with sterile distilled water to remove the trace elements of media. Wet biomass of $1.5 \mathrm{~g}$ of culture was then suspended in $30 \mathrm{ml}$ of double distilled water and boiled at $80^{\circ} \mathrm{C}$ for 30 minutes in an Erlenmeyer flask. After boiling, the mixture was cooled and centrifuged at 5,000 rpm for 15 minutes and the supernatant was collected for biosynthesis (Jena et al., 2013).

\section{Extracellular synthesis of silver nanoparticles}

One hundred millimeter of $\mathrm{AgNO}_{3}$ (Sigma Aldrich) solution ( $\mathrm{pH} 7.0$ ) was prepared. About $1 \mathrm{ml}$ of cell-free extract was added to $19 \mathrm{ml}$ of $\mathrm{AgNO}_{3}$ solution and was incubated at $25^{\circ} \mathrm{C} \pm 1{ }^{\circ} \mathrm{C}$ under cool white fluorescent light $(50 \mu \mathrm{mol}$ photons $\mathrm{m}^{-2} \mathrm{~s}^{-1}$ ) and in the dark condition for 72 hours of incubation. A freshly prepared BG11 medium with $\mathrm{AgNO}_{3}$ was used as control. During the incubation period, the change in color from pale yellowish green to brown indicated the synthesis of nanoparticles. The color change to a darker brownish color was time-dependent and it was quantified by absorbance spectra recording during the 72 hours of incubation period. One $\mathrm{ml}$ aliquot sample were taken every 12 hours, and the absorbance of the UV-Vis spectra at a resolution of $1 \mathrm{~nm}$ in the range of 300-800 $\mathrm{nm}$ were recorded by using a spectrophotometer (Shimadzu, Model: UV-2450).

\section{Electron microscopic analysis}

TEM images were obtained from an FEI TECHNAI $\mathrm{G}_{2}$ TEM operating at an accelerating voltage of 200 KV. Samples were set up by putting a drop of sample solution on the carboncovered copper grid and dried under an infrared light preceding the assessment. Crystallinity of structures was affirmed by the selected area's electron diffraction pattern (Jena et al., 2013).

\section{Scanning electron microscopy}

SEM analysis (Hitachi, model: S-3400N) was used to observe the microalgal cell with entrapped silver nanoparticles. On a carbon coated copper grid, thin films of sample were prepared and dried under a mercury lamp for 5 minutes (Issa, 1999).

\section{Fourier transform infrared spectroscopy analysis}

For FTIR spectroscopy, freeze-dried, cell-free extract silver nanoparticles were utilized. A limited quantity of dried biomass with potassium bromide $(\mathrm{KBr})$ was crushed together. PerkinElmer FTIR system Spectrum GX model was used to record the sample spectrum with the measurements being carried out in the range of $400-4,000 \mathrm{~cm}^{-1}$ at a resolution of $4 \mathrm{~cm}^{-1}$.

\section{Antibacterial activity of CSNPs}

CSNPs were tested for antibacterial activity, suggested by Srinivasulu et al. (2002). Gram-positive and Gram- negative bacteria like Staphylococus aureus (MTCC-3381), Escherichia coli (MTCC-1541), Klebsiella pneumonia (MTCC-3384), Salmonella paratyphi (MTCC-3220), and Micrococcus luteus (MTCC-1541), procured from the Microbial Type Culture Collection Center (Chandigarh), were used as test organisms. The test organisms were grown in fresh nutrient broth for 24 hours. The antibacterial activity was carried out by agar well diffusion method. Bacterial lawns were prepared by spreading 
the bacterial suspension of $100 \mu \mathrm{l}\left(1 \times 10^{5} \mathrm{CFU} / \mathrm{ml}\right)$ on the surface of the agar plates. Agar wells (6 $\mathrm{mm}$ in size) were punched on the agar plates using a sterile stainless steel cork borer. The wells were loaded with 40,60 , and $80 \mu \mathrm{l}$ of CSNPs with the same quantity of $\mathrm{AgNO}_{3}$ as the negative control along with $30 \mu \mathrm{g} / \mathrm{ml}$ streptomycin as the positive control. The plates were incubated for 24 hours at $37^{\circ} \mathrm{C}$ and then examined for the presence of inhibition zones. The inhibition zone diameter was measured and the mean value for each organism was recorded and the relative percentage of inhibition with respect to positive control was calculated.

\section{Cytotoxicity of silver nanoparticles}

CSNPs were tested on MCF-7 breast cancer cell lines and human hepatocellular carcinoma (HepG2) cell lines using MTT-based cell cytotoxicity assay. The cells were procured from the National Centre for Cell Science, Pune, India. The harvested cells were cultivated in RPMI media with $10 \%$ fetal bovin serum, $1 \%$ of L-gultamin, and $1 \%$ of penicillin $(100 \mathrm{U} /$ $\mathrm{ml})$ along with $1 \%$ streptomycin $(100 \mu \mathrm{g} / \mathrm{ml})$. The cells in the media are diluted to the cell density from $1 \times 10^{6}$ to $1 \times 10^{3}$ i.e., $1,000-10,000$ cells per well. The cells were seeded in a 96-well micro-titer plate by adding $100 \mu \mathrm{l}$ per well in triplicate. The plates were incubated at $37^{\circ} \mathrm{C}$ in $\mathrm{COD}$ incubator maintain $5 \%$ $\mathrm{CO}_{2}$, allowing the cells to adhere overnight. After incubation, the media was discarded, and the wells were treated with CSNPs with concentrations of $100,75,50,25$, and $5 \mu \mathrm{g} / \mathrm{ml}$ and incubated at $5 \% \mathrm{CO}_{2}$ for 24,48 , and 72 hours, according to the study of test sample. The well with untreated cells was maintained as control.

\section{RESULTS AND DISCUSSION}

The synthesis of silver nanoparticles by $C$. turgidus and C. typicum was confirmed by color change from pale yellow to reddish brown. The intensity of color increased with the time of incubation till 72 hours. Synthesis of AgNPs by cyanobacterial cells was determined by studying the UV absorbance peak in the range of 300-800 nm (Shimazu, Model: UV-2450) because of the strong absorption of visible light due to excitation of the nanoparticles associated with surface plasmon resonance, which is a significant property of silver nanoparticles (Banerjee et al., 2014; Hartland et al., 2011; Krishnaraj et al.,
2010; Kwon et al., 2012). The color change of $\mathrm{AgNO}_{3}$ solution was observed only under light conditions by both the strains (Fig. 1). The UV absorbance of cell-free extract of C. typicum showed the wide peak with 0.663 at $435 \mathrm{~nm}$ (Fig. 2), whereas UV absorbance peak of 2.646 at $442 \mathrm{~nm}$ for cell-free extract of C. turgidus was observed (Fig. 3). Silver nanoparticle synthesis by cyanobacterial cells at 420 and $470 \mathrm{~nm}$, corresponding to the plasmon absorbance suggested that cyanobacterial extract is efficient in nanoparticle synthesis. According to Pal et al. (2007), a narrow peak at $425 \mathrm{~nm}$ and a wide peak at $490 \mathrm{~nm}$ corresponded to 29 and $89 \mathrm{~nm}$ silver nanoparticles, respectively. Reduction of silver ions to silver nanoparticles may be due to capping of microalgal protein metabolites (Sudha et al., 2013). It is reported that the absorption spectrum of silver nanoparticle present maximum peak height between 420 and $450 \mathrm{~nm}$ with a blue or red shift with increment in particle size (Pal et al., 2007; Sönnichsen et al., 2002).

\section{Characterization of CSNPsScanning electron microscopy}

The morphology and characterization of biosynthesized silver nanoparticles by the bio-reduction of cell-free extract of $C$. turgidus and C. typicum were revealed through SEM studies. The light microscopy showed that the bio-reduced silver nanoparticles seemed to be trapped on the cellular structures either in aggregates or dispersed. Further study showed that the size of the particle synthesized by cell-free extract ranged between 22 and $34 \mathrm{~nm}$, and nanoparticles synthesized by biomass are mostly oval in shape (Figs. 4 and 5).

\section{Transmission electron microscopy}

TEM analysis provided information regarding the morphology and shape of the synthesized nanoparticle. The results were interpreted through images of TEM and revealed that the size and shape of the synthesized particles varied significantly among species. The dispersion of nanoparticles was evenly distributed in the cell-free extract with shape of the particles varying from spherical to oval and irregular shapes. TEM analysis showed the synthesis of polydisperse AgNPs in the range of $20 \mathrm{~nm}$, with an average size of $18.10 \mathrm{~nm}$ in $C$. turgidus (Fig. 6), with the smallest particle size being $9.87 \mathrm{~nm}$, an average of $20.67 \mathrm{~nm}$ in C. typicum (Fig. 7), and the smallest particle size was $19.78 \mathrm{~nm}$.

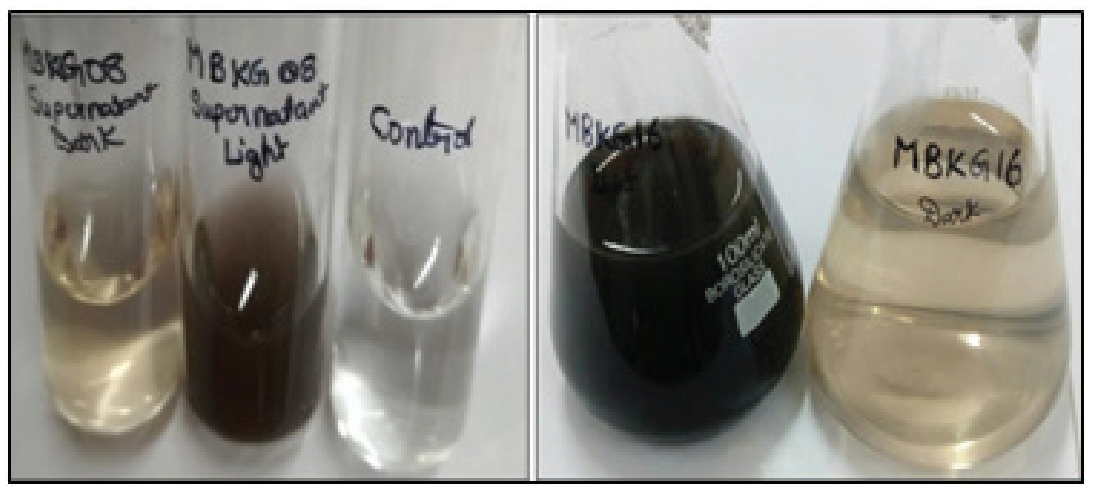

Figure 1. Synthesis of silver nanoparticles under light and dark conditions 


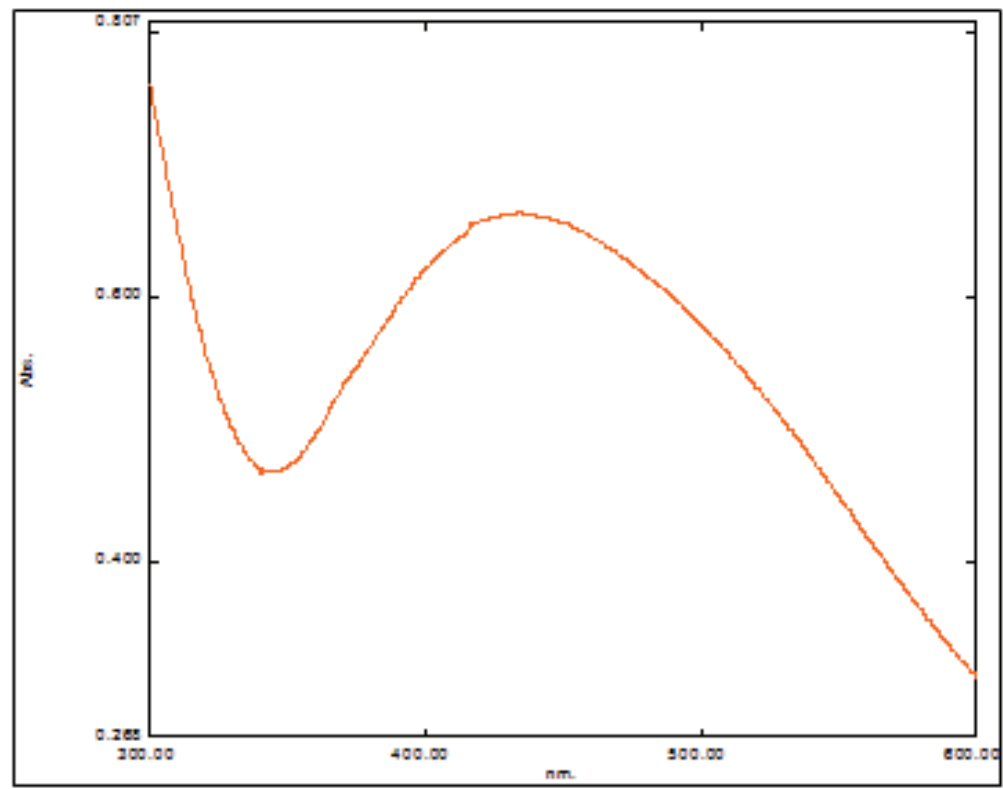

Figure 2. C. typicum cell-free extract 72 hours.

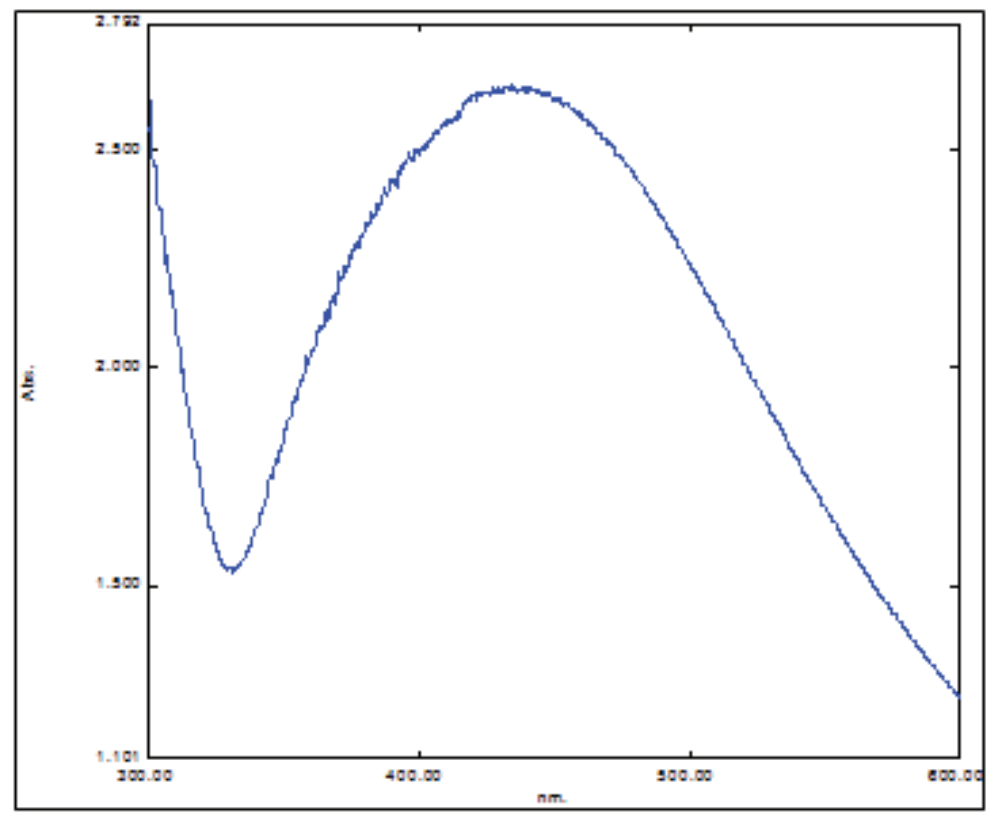

Figure 3. C. turgidus cell-free extract 72 hours.

Fourier transform infrared analysis

FTIR spectroscopy is an epic tool that uses electromagnetic radiation frequencies for verification of organic compound and structure determination between 4,000 and 400 $\mathrm{cm}^{-1}$ of frequency. Chemical bonds of different compounds absorb different intensities at different frequencies. Therefore, IR spectroscopy works by collecting absorption information, analyzes it, and gives the output in the form of spectrum. The peak and signal frequencies of absorption are directly relate to the bonds within the compound (Smith, 2018; Yang et al., 2015). FTIR analysis was carried out on C. turgidus and C. typicum silver nanoparticles synthesized from cell-free extract. The FTIR spectral peaks were compared with control, i.e., cell extract without $\mathrm{AgNO}_{3}$.

The IR spectra of bio-reduced silver nanoparticles by C. turgidus cell-free extract showed a major vibration band at $3,440.87 \mathrm{~cm}^{-1}$, which is generally assigned to $\mathrm{N}-\mathrm{H} 1^{0}$ amine or amide with $\mathrm{O}-\mathrm{H}$ bend of alcohols. The similar stretching bands were observed ranging at $1,382-1,386 \mathrm{~cm}^{-1}$, which is assigned to the protein bending of methyl, $v_{\mathrm{s}}(\mathrm{C}-\mathrm{O})$ of carboxylic acid, and $\mathrm{C}-\mathrm{F}$ stretch of the alkyl halide functional group. Another band was at 


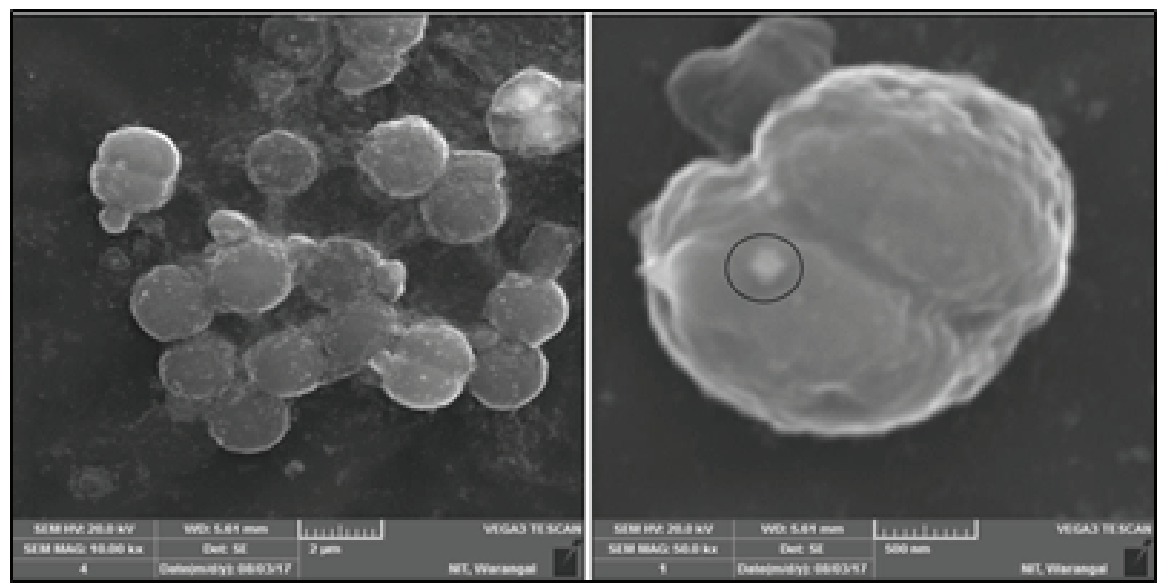

Figure 4. SEM images of C. turgidus with spherical shaped nanoparticles.

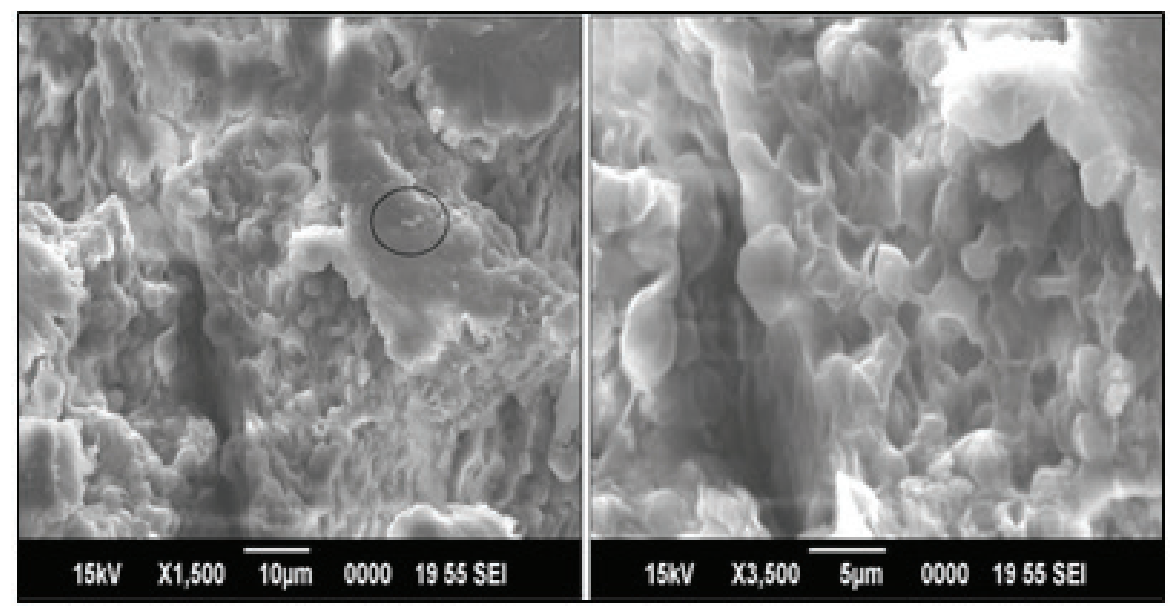

Figure 5. SEM images of C. typicum with spherical shaped nanoparticles.

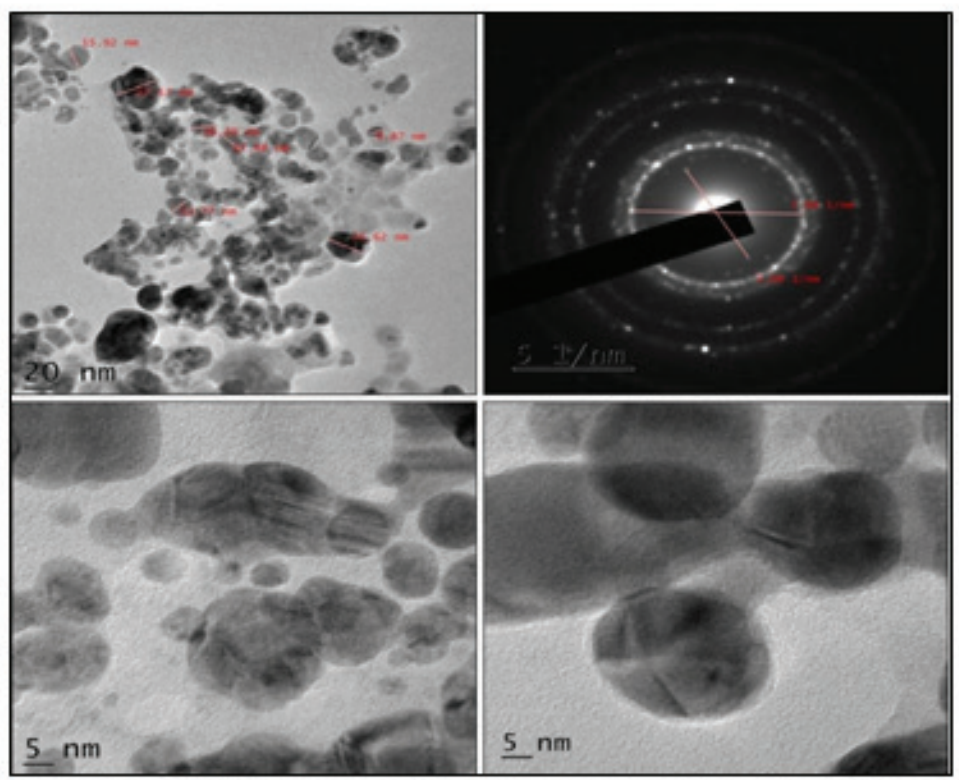

Figure 6. TEM images of C. turgidus. 
the range of 1,023-1027 $\mathrm{cm}^{-1}$, which was assigned to carbohydrate (C-O-C) polysaccharide (Fig. 8). Inasmuch as C. typicum cellfree extract silver nanoparticles IR spectral data revealed a band at $3,450.44 \mathrm{~cm}^{-1}$, which is assigned to $2^{0}$ amide in the $\mathrm{N}-\mathrm{H}$ stretch, $1,382.42 \mathrm{~cm}^{-1}$ is assigned to protein $\delta_{\text {as }}\left(\mathrm{CH}_{2}\right)$ and $\delta_{\text {as }}\left(\mathrm{CH}_{3}\right)$ bending of methyl, carboxylic acid $v_{s}(\mathrm{C}-\mathrm{O})$, and $\mathrm{C}-\mathrm{F}$ stretch of alkyl halide (Fig. 9). The frequency bands were compared with control FTIR spectra by noting the appearance of new bands in the FTIR spectra of cell-free extract of cyanobacterial strains at $\mathrm{N}-\mathrm{H}$ peaks of $1^{0}$ and $2^{0}$ amide (Fig. 10).

\section{Antibacterial activity of biosynthesized silver nanoparticles}

The antibacterial activity of biosynthesized silver nanoparticles of two cyanobacterial strains were studied against
S. aureus (MTCC-3381), E. coli (MTCC-1541), K. pneumonia (MTCC-3384), S. paratyphi (MTCC-3220), and M. luteus (MTCC-1541), through agar-well diffusion method. The agar well was loaded with 40,60 , and $80 \mu \mathrm{l}$ with silver nanoparticles along with streptomycin as the negative control and silver nitrate as the positive control. $80 \mu \mathrm{l}$ silver nanoparticle solution of $C$. turgidus and $\mathrm{C}$. typicum showed high biocidal activity against $S$. paratyphi with 4.1 and $6.9 \mathrm{~mm}$ zone of inhibition, 3.3 and 4 $\mathrm{mm}$ zone of inhibition against $E$. coli, respectively, whereas 60 $\mu 1$ silver nanoparticle solution of $C$. typicum showed $4.2 \mathrm{~mm}$ zone of inhibition against $S$. paratyphi as seen in Table 1 ; the antibacterial activity plates clearly showed the zone of inhibition (Fig. 11).

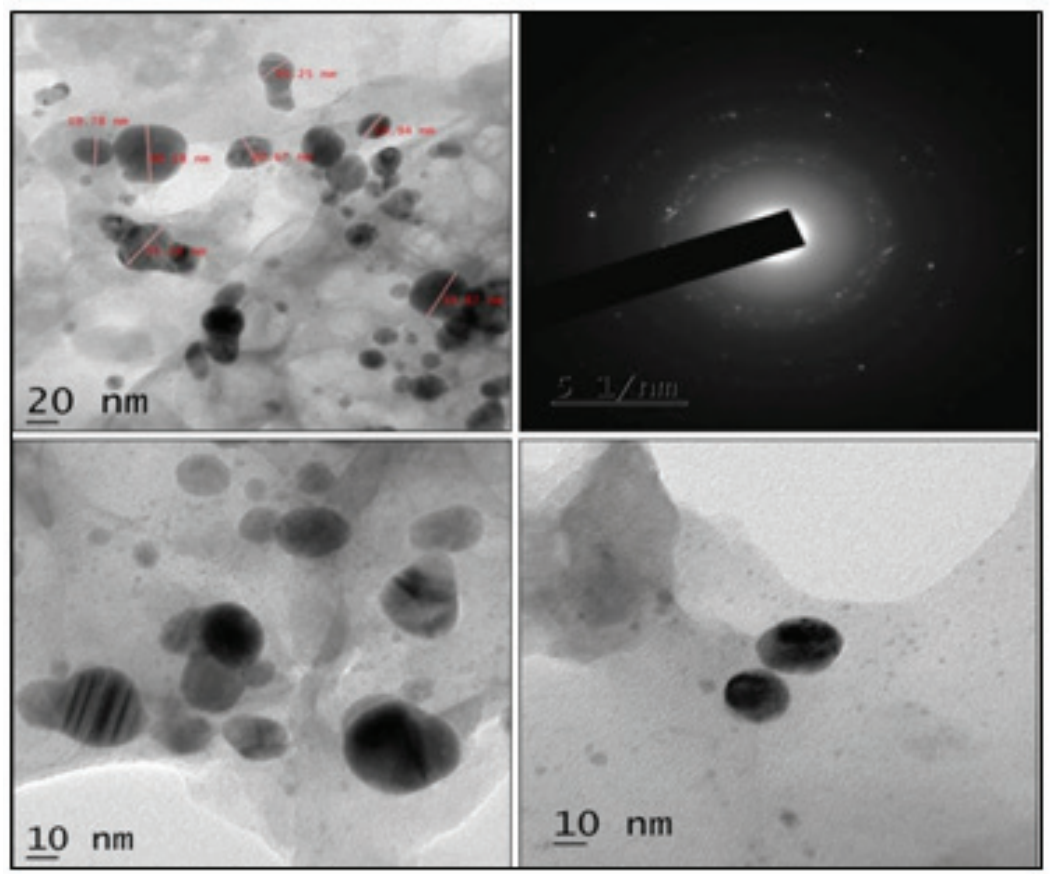

Figure 7. TEM images of C. typicum.

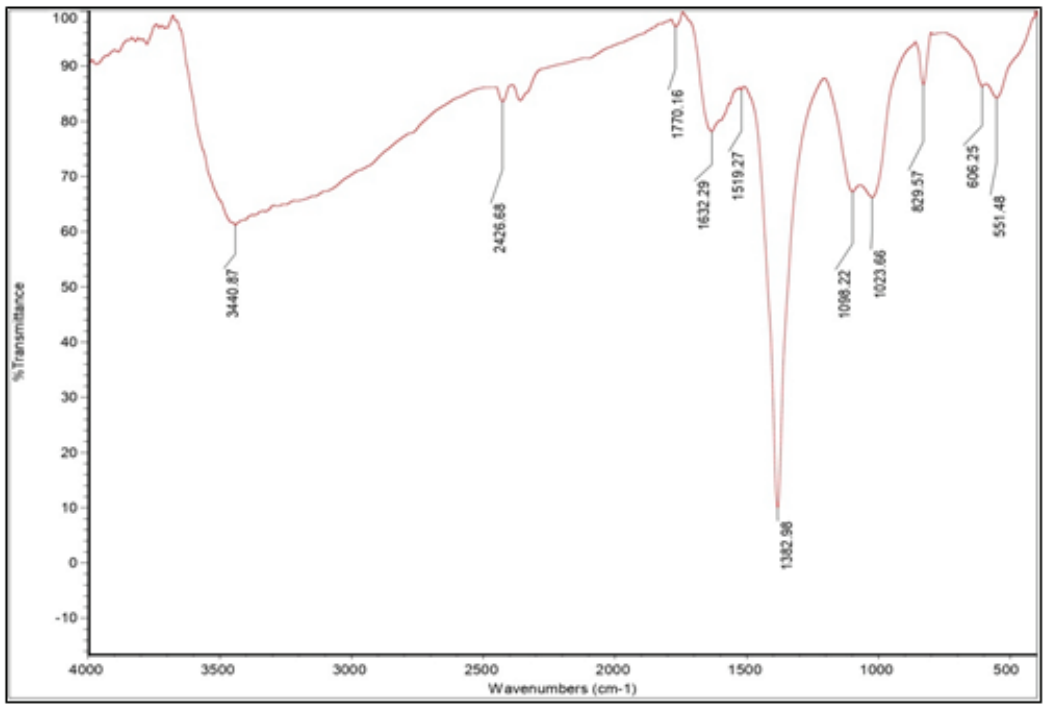

Figure 8. FTIR spectra of C. turgidus cell-free extract silver nanoparticles. 


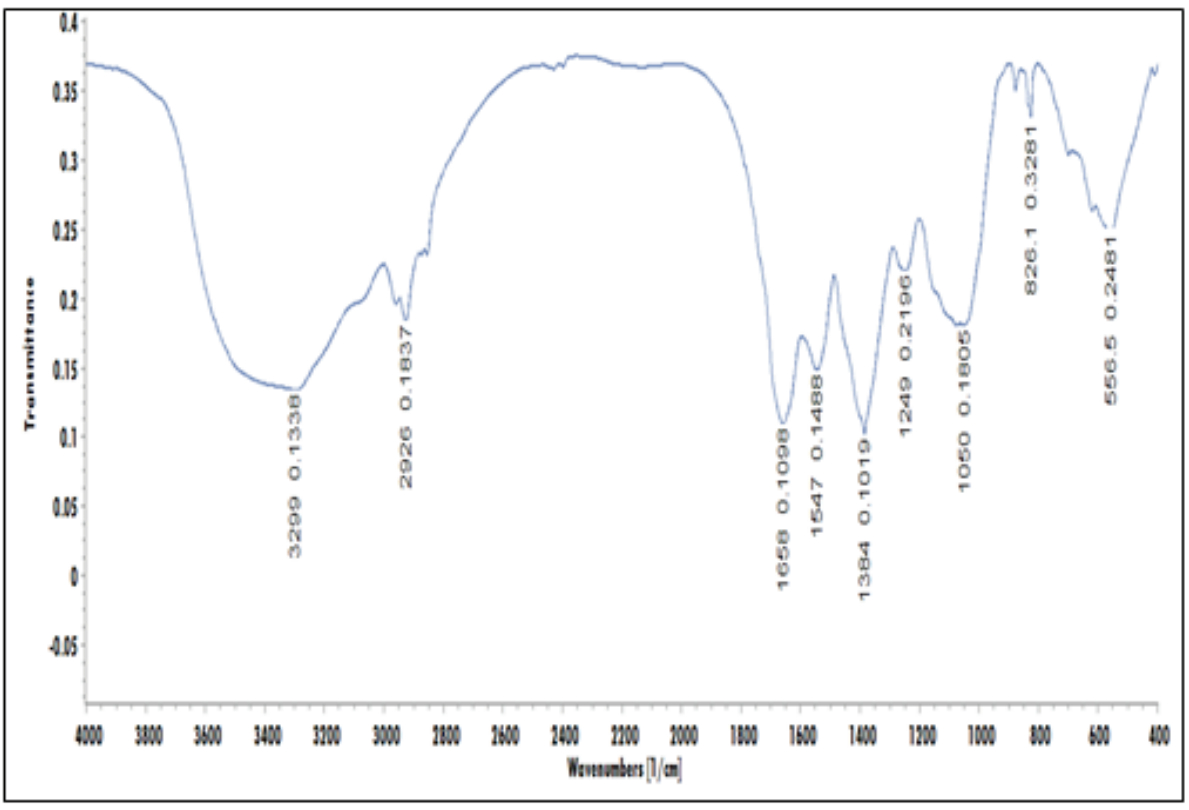

Figure 9. FTIR spectra of C. turgidus control.

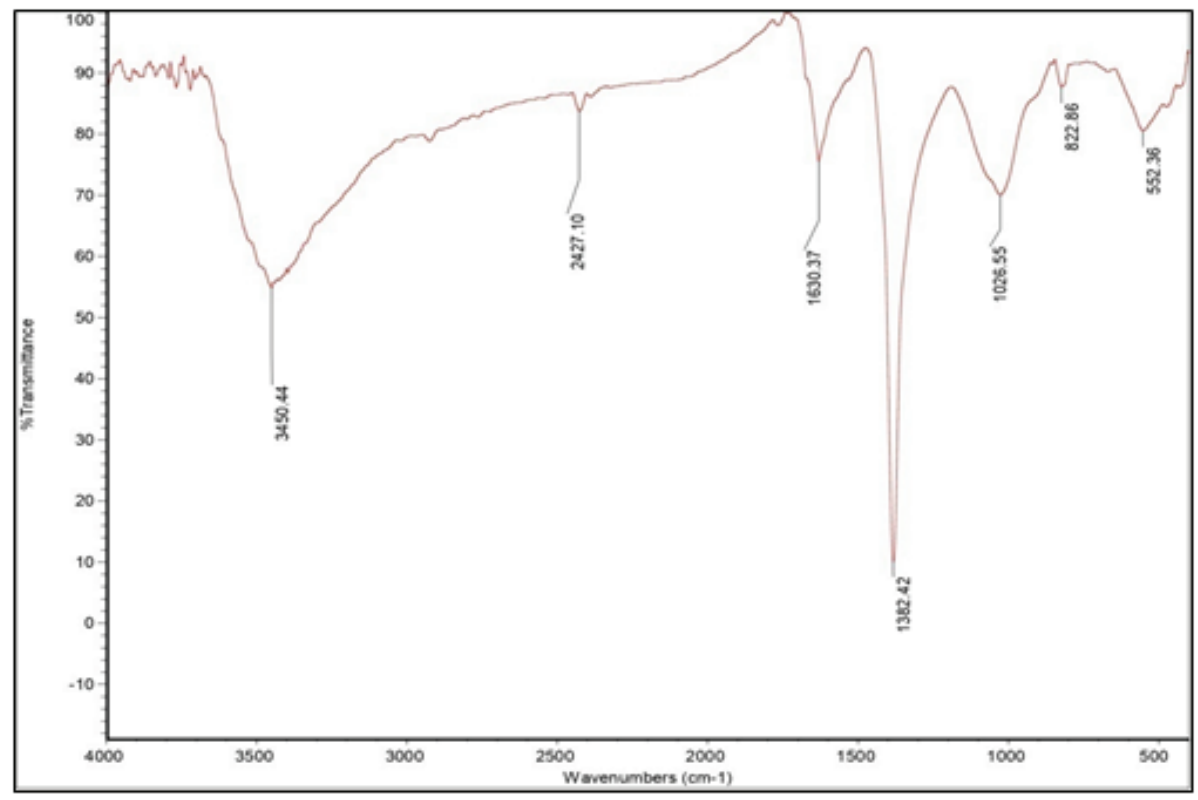

Figure 10. FTIR spectra of $C$. turgidus silver nanoparticles by cell-free extract.

Cytotoxic assayThe MTT cell assay works on the principle for determination of cell viability, cell proliferation, and effect of cytotoxic chemical entities. The assay is the quantitative measurement of insoluble formazan crystals formed through the reduction of the yellow colored water soluble Tetrazolium dye, i.e., MTT extracellularly by metabolically active cells that are conciliated by lactate dehydrogenase of mitochondria. The color intensity of formazan crystals is directly proportional to the number of viable cells which are assessed spectrophotometrically at $570 \mathrm{~nm}$ (Van Meerloo et al., 2011; Tolosa et al., 2015). The assay procedure includes reconstitution of the preestimated MTT reagent in the assay buffer, trailed by its addition to the culture system. Subsequent to dissolving the formazan crystals in the solubilization solution, results can be directly perused.

In vitro cytotoxicity studies carried out by silver nanoparticles of three cyanobacterial strains dissolved in DMSO were evaluated against MCF-7 breast cancer and HepG2 cell lines with different concentration of 5, 10, 25, 50, 75, and $100 \mathrm{ug} / \mathrm{ml}$ for each sample in comparison with the standard tamoxafin drug. All three cyanobacteria-mediated silver nanoparticles cytotoxicity were dose-dependent and compared with untreated cells. The cytotoxic activity of $\mathrm{C}$. typicum against MCF-7 breast cancer cells 
Table 1. Antibacterial activity of CSNPs against pathogenic bacteria.

\begin{tabular}{|c|c|c|c|c|c|c|}
\hline \multirow{2}{*}{ Samples } & \multirow[b]{2}{*}{ Conc } & \multicolumn{5}{|c|}{ Zone of inhibition (diameter in $\mathbf{m m}$ ) } \\
\hline & & E. coli & S. aureus & S. paratyphi & K. pneumoniae & M. luteus \\
\hline \multirow{3}{*}{ Silver nitrate (positive control) } & $40 \mu 1$ & 1.0 & 1.0 & 1.0 & 1.0 & 1.0 \\
\hline & $60 \mu \mathrm{l}$ & 1.0 & 1.0 & 1.0 & 1.0 & 1.0 \\
\hline & $80 \mu \mathrm{l}$ & 1.0 & 1.0 & 1.0 & 1.0 & 1.0 \\
\hline \multirow{3}{*}{$\begin{array}{c}\text { Streptomycin } \\
\text { (Negative control) }\end{array}$} & $40 \mu 1$ & 8.0 & 8.0 & 8.0 & 8.0 & 8.0 \\
\hline & $60 \mu 1$ & 8.0 & 8.0 & 8.2 & 9.0 & 9.0 \\
\hline & $80 \mu \mathrm{l}$ & 10 & 11 & 13 & 13 & 13 \\
\hline \multirow{3}{*}{ C. turgidus } & $40 \mu \mathrm{l}$ & 1.0 & 1.0 & 1.0 & 1.0 & 1.0 \\
\hline & $60 \mu \mathrm{l}$ & 1.0 & 1.2 & 2.0 & 1.0 & 1.0 \\
\hline & $80 \mu \mathrm{l}$ & 4.0 & 2.0 & 4.1 & 2.0 & 1.4 \\
\hline \multirow{3}{*}{ C. typicum } & $40 \mu \mathrm{l}$ & 1.0 & 1.2 & 1.3 & 1.0 & 1.0 \\
\hline & $60 \mu \mathrm{l}$ & 2.0 & 2.0 & 4.2 & 1.5 & 1.0 \\
\hline & $80 \mu \mathrm{l}$ & 3.3 & 3.0 & 6.9 & 2.0 & 3.0 \\
\hline
\end{tabular}
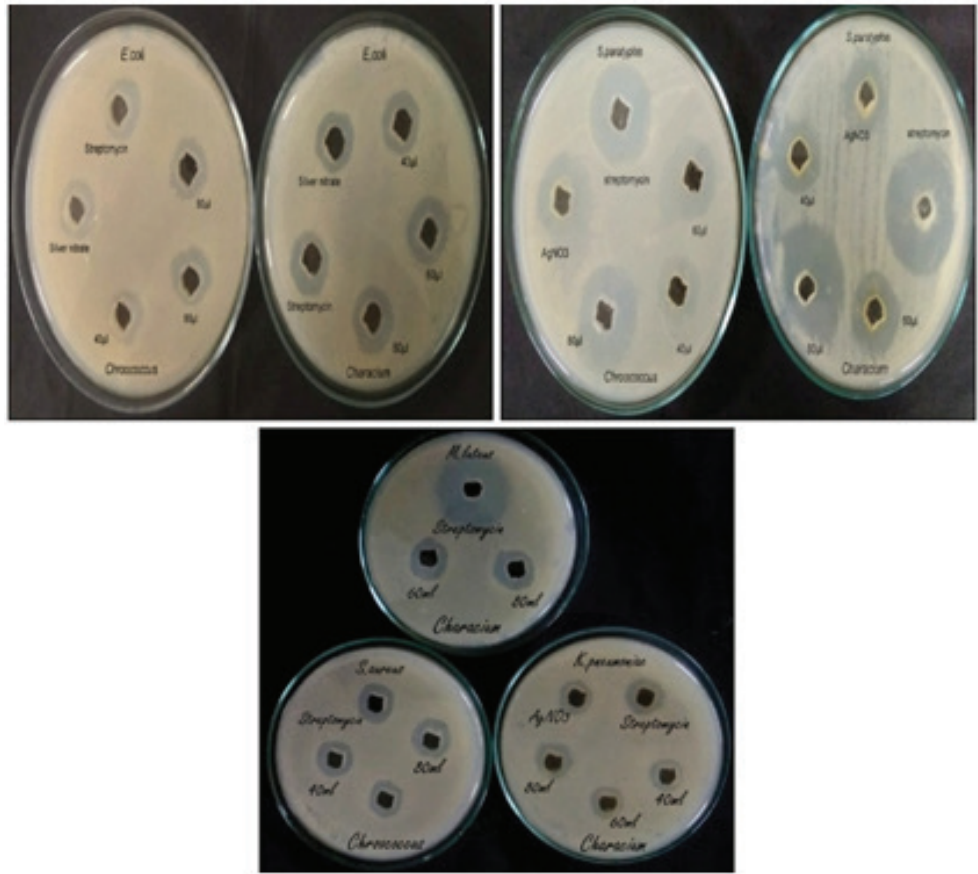

Figure 11. Antibacterial activity.

of $5 \mathrm{ug} / \mathrm{ml}$ concentration showed the cell viability of $64.7 \%$ then decreased to $33.4 \%$ by $100 \mathrm{ug} / \mathrm{ml}$ concentration; this explains the death of cancer cells increased by increasing concentration of silver nanoparticles (Table 2). The overall cytotoxicity of C. typicum against MCF-7 breast cancer cells gave the $\mathrm{IC}_{50}$ value of 43.375 $\mathrm{ug} / \mathrm{ml} . \mathrm{IC}_{50}$ is the half maximal inhibitory concentration which is the measure of the potency of a drug in inhibiting biological cell growth. The cytotoxic activity of C. turgidus against MCF-7 breast cancer cells resulted in decrease of cell viability from $64.1 \%$ to $32.7 \%$ and from 5 to $100 \mathrm{ug} / \mathrm{ml}$ concentration, respectively, giving out the $\mathrm{IC}_{\mathbf{5 0}}$ value of $40.917 \mathrm{ug} / \mathrm{ml}$ (Table 3 ).
The cytotoxic activity of cell-free extract silver nanoparticles against HepG2 cancer cell line by $C$. typicum showed the cell viability of $59.3 \%$ with $5 \mathrm{ug} / \mathrm{ml}$ concentration, where $100 \mathrm{ug} / \mathrm{ml}$ showed $27.03 \%$ viability with $\mathrm{IC}_{\mathbf{5 0}}$ value of 20.8 $\mathrm{ug} / \mathrm{ml}$ (Table 4). The cytotoxicity of $C$. turgidus killed the cell with $40.9 \%$ cell viability with $100 \mathrm{ug} / \mathrm{ml}$ concentration, whereas $5 \mathrm{ug} / \mathrm{ml}$ concentration showed more cell viability of $63.3 \%$, and the $\mathrm{IC}_{\mathbf{5 0}}$ value of MBKG 35 silver nanoparticles against HepG2 cancer cell line was $55.7 \mathrm{ug} / \mathrm{ml}$ (Table 5). The cell viability was observed under a compound microscope in the $\mathrm{T}_{25}$ cell culture flask (Fig. 12). 
Table 2. Cytotoxic properties of C. typicum on MCF-7 breast cancer cell line

\begin{tabular}{|c|c|c|c|c|c|c|c|}
\hline \multirow{2}{*}{$\frac{\text { Concentration }(\mu \mathrm{g} / \mathrm{ml})}{100}$} & \multicolumn{3}{|c|}{ Absorbance at $570 \mathrm{~nm}$} & \multirow{2}{*}{$\frac{\text { Average }}{0.433}$} & \multirow{2}{*}{$\frac{\text { Average-blank }}{0.425}$} & \multirow{2}{*}{$\frac{\text { \% Viability }}{33.464}$} & \multirow[t]{2}{*}{$\mathrm{IC}_{50}(\mu \mathrm{g} / \mathrm{ml})$} \\
\hline & 0.431 & 0.433 & 0.435 & & & & \\
\hline 75 & 0.513 & 0.515 & 0.517 & 0.515 & 0.507 & 39.921 & \multirow{5}{*}{43.375} \\
\hline 50 & 0.595 & 0.596 & 0.597 & 0.596 & 0.588 & 46.299 & \\
\hline 25 & 0.686 & 0.688 & 0.689 & 0.687 & 0.679 & 53.464 & \\
\hline 10 & 0.774 & 0.776 & 0.778 & 0.776 & 0.768 & 60.472 & \\
\hline 5 & 0.829 & 0.83 & 0.832 & 0.83 & 0.822 & 64.724 & \\
\hline Untreated & 1.278 & 1.279 & 1.278 & 1.278 & 1.27 & 100 & \\
\hline Blank & 0.008 & 0.009 & 0.008 & 0.008 & 0 & & \\
\hline
\end{tabular}

Table 3. Cytotoxic properties of C. turgidus on MCF-7 breast cancer cell line.

\begin{tabular}{|c|c|c|c|c|c|c|c|}
\hline \multirow{2}{*}{$\frac{\text { Concentration }(\mu \mathrm{g} / \mathrm{ml})}{100}$} & \multicolumn{3}{|c|}{ Absorbance at $570 \mathrm{~nm}$} & \multirow{2}{*}{$\frac{\text { Average }}{0.424}$} & \multirow{2}{*}{$\frac{\text { Average-blank }}{0.416}$} & \multirow{2}{*}{$\frac{\% \text { Viability }}{32.755}$} & \multirow[t]{2}{*}{$\mathrm{IC}_{50}(\mu \mathrm{g} / \mathrm{ml})$} \\
\hline & 0.423 & 0.425 & 0.426 & & & & \\
\hline 75 & 0.503 & 0.505 & 0.507 & 0.505 & 0.497 & 39.133 & \multirow{5}{*}{40.917} \\
\hline 50 & 0.582 & 0.584 & 0.585 & 0.583 & 0.575 & 45.275 & \\
\hline 25 & 0.675 & 0.679 & 0.68 & 0.678 & 0.67 & 52.755 & \\
\hline 10 & 0.768 & 0.77 & 0.771 & 0.769 & 0.761 & 59.921 & \\
\hline 5 & 0.82 & 0.822 & 0.823 & 0.821 & 0.813 & 64.015 & \\
\hline Untreated & 1.278 & 1.279 & 1.278 & 1.278 & 1.27 & 100 & \\
\hline Blank & 0.008 & 0.009 & 0.008 & 0.008 & 0 & & \\
\hline
\end{tabular}

Table 4. Cytotoxic properties of C. typicum on HepG2 cell line

\begin{tabular}{|c|c|c|c|c|c|c|c|}
\hline Concentration(ug/ml) & \multicolumn{3}{|c|}{ Absorbance at $570 \mathrm{~nm}$} & Average & Average-blank & $\%$ Viability & $\mathrm{IC}_{50}(\mathrm{ug} / \mathrm{ml})$ \\
\hline 100 & 0.332 & 0.334 & 0.336 & 0.334 & 0.326 & 27.031 & \multirow{8}{*}{20.880} \\
\hline 75 & 0.441 & 0.443 & 0.445 & 0.443 & 0.435 & 36.069 & \\
\hline 50 & 0.515 & 0.517 & 0.518 & 0.516 & 0.508 & 42.122 & \\
\hline 25 & 0.553 & 0.555 & 0.556 & 0.554 & 0.546 & 45.273 & \\
\hline 10 & 0.612 & 0.614 & 0.616 & 0.614 & 0.606 & 50.248 & \\
\hline 5 & 0.722 & 0.724 & 0.726 & 0.724 & 0.716 & 59.369 & \\
\hline Untreated & 1.214 & 1.215 & 1.214 & 1.214 & 1.206 & 100 & \\
\hline Blank & 0.008 & 0.009 & 0.008 & 0.008 & 0 & & \\
\hline
\end{tabular}

Table 5. Cytotoxic properties of C. turgidus on HepG2 cell line.

\begin{tabular}{|c|c|c|c|c|c|c|c|}
\hline \multirow{2}{*}{$\begin{array}{c}\text { Concentration(ug/ml) } \\
100\end{array}$} & \multicolumn{3}{|c|}{ Absorbance at $570 \mathrm{~nm}$} & \multirow{2}{*}{$\begin{array}{c}\text { Average } \\
0.623\end{array}$} & \multirow{2}{*}{$\begin{array}{c}\text { Average-blank } \\
0.617\end{array}$} & \multirow{2}{*}{$\frac{\text { \% Viability }}{40.942}$} & \multirow{2}{*}{$\mathrm{IC}_{50}(\mathrm{ug} / \mathrm{ml})$} \\
\hline & 0.622 & 0.624 & 0.625 & & & & \\
\hline 75 & 0.693 & 0.695 & 0.696 & 0.694 & 0.688 & 45.653 & \multirow{5}{*}{55.772} \\
\hline 50 & 0.765 & 0.766 & 0.768 & 0.766 & 0.76 & 50.431 & \\
\hline 25 & 0.844 & 0.846 & 0.847 & 0.845 & 0.839 & 55.673 & \\
\hline 10 & 0.896 & 0.897 & 0.899 & 0.897 & 0.891 & 59.124 & \\
\hline 5 & 0.959 & 0.961 & 0.963 & 0.961 & 0.955 & 63.37 & \\
\hline Untreated & 1.513 & 1.514 & 1.513 & 1.513 & 1.507 & 100 & \\
\hline Blank & 0.006 & 0.007 & 0.006 & 0.006 & 0 & & \\
\hline
\end{tabular}




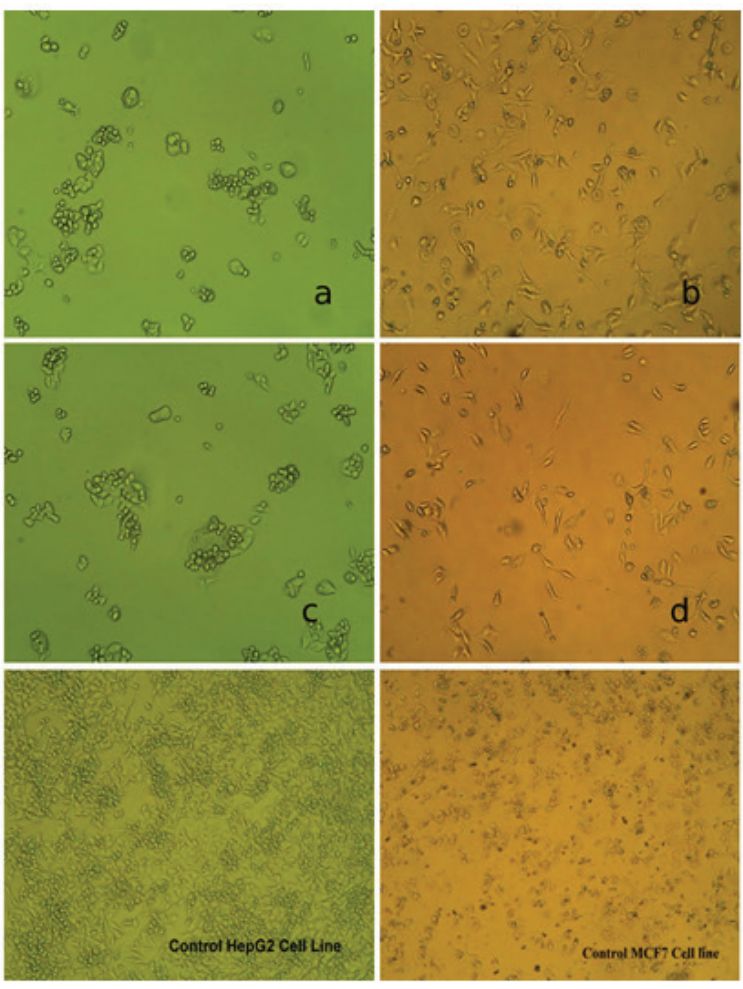

Figure 12. (a) Cytotoxic activity of C. typicum on HepG2 Cell line; (b) cytotoxic activity of C. turgidus on HepG2 Cell line; (c) cytotoxic activity of C. typicum on MCF-7 breast cancer cell line; (d) cytotoxic activity of C. turgidus on MCF-7 breast cancer cell line.

\section{CONCLUSION}

Our present study indicates that the green synthesis of silver nanoparticles by biological protocol using isolated purified C. typicum and $C$. turgidus cell-free extract acted as both equally reducing and stabilizing agents for the successful bio-reduction of nanoparticles. The characterization study using UV-Vis, FTIR, SEM, and TEM detailed that the synthesized nanoparticles were 19-34 nm in size and the proteins and polysaccharides were important factors in the biosynthesis of silver nanoparticles. Because of their small size, the silver nanoparticles were able to exhibit some synergetic bactericidal potentiality against human pathogenic bacteria, such as $S$. paratyphi and E. coli. Silver nanoparticles of C. typicum and $C$. turgidus exerted significant cytotoxicity against MCF-7 and HepG2 cancer cell lines. Our study emphasized that this approach was simple, eco-friendly, and efficient, which resulted in the production of silver nanoparticles without the use of any toxic reducing or dispersing agents at an ambient temperature.

\section{ACKNOWLEDGMENT}

The authors are thankful to the University Grant Commission - RGNF (Rajiv Gandhi National Fellowship) F117.1/2014-15/RGNF-2014-15-SC-AND-57992, New Delhi, India, for providing financial assistance to carry out this research work.

\section{CONFLICT OF INTEREST}

The authors declare that they have no conflicts of interest.

\section{FINANCIAL SUPPORT AND SPONSORSHIP}

None.

\section{REFERENCES}

Ali DM, Sasikala M, Gunasekaran M, Thajuddin N. Biosynthesis and characterization of silver nanoparticles using marine cyanobacterium, Oscillatoria willei NTDM01. Dig J Nanomater Biostruct, 2011; 6:385-90.

AL-Sultan EY. Isolation, purification and identification of bluegreen alga Hapalosiphon aureus and evaluation of its histopathological effects on fresh water snail Lymnaea auricularia. J Appl Sci, 2017; 17:61-71.

Banerjee P, Satapathy M, Mukhopahayay A, Das P. Leaf extract mediated green synthesis of silver nanoparticles from widely available Indian plants: synthesis, characterization, antimicrobial property and toxicity analysis. Bioresour Bioprocess, 2014; 1:3.

Chlipala GE, Mo S, Orjala J. Chemodiversity in freshwater and terrestrial cyanobacteria-a source for drug discovery. Curr Drug Targets, $2011 ; 12: 1654-73$

Hartland GV. Optical studies of dynamics in noble metal nanostructures. Chem Rev, 2011; 111:3858-87.

Husain S, Sardar M, Fatma T. Screening of cyanobacterial extracts for synthesis of silver nanoparticles. World J Microbiol Biotechnol, $2015 ; 31: 1279-83$.

Issa AA. Antibiotic production by the cyanobacteria Oscillatoria angustissima and Calothrix parietina. Environ Toxicol Pharmacol, 1999; 8:33-7.

Jeffryes C, Agathos SN, Rorrer G. Biogenic nanomaterials from photosynthetic microorganisms. Curr Opin Biotechnol, 2015; 33:23-31.

Jena J, Pradhan N, Dash BP, Sukla LB, Panda PK. Biosynthesis and characterization of silver nanoparticles using microalga Chlorococcum humicola and its antibacterial activity. Int J Nanomater Biostruct, 2013; $3: 1-8$.

Keskin S, Oya N, Koçberber Kılıç N, Dönmez G, Tekinay T. Green synthesis of silver nanoparticles using cyanobacteria and evaluation of their photocatalytic and antimicrobial activity. J Nano Res, 2016; 40:120-7.

Kharissova OV, Dias HR, Kharisov BI, Pérez BO, Pérez VM. The greener synthesis of nanoparticles. Trends Biotechnol, 2013; 31:240-8.

Kim SK. Handbook of marine macroalgae: biotechnology and applied phycology. John Wiley \& Sons, Hoboken, NJ, 2011.

Krishnaraj C, Jagan EG, Rajasekar S, Selvakumar P, Kalaichelvan PT, Mohan NJ. Synthesis of silver nanoparticles using Acalypha indica leaf extracts and its antibacterial activity against water borne pathogens. Colloids Surf B Biointerfaces, 2010; 76:50-6.

Kwon MJ, Lee J, Wark AW, Lee HJ. Nanoparticle-enhanced surface plasmon resonance detection of proteins at attomolar concentrations: comparing different nanoparticle shapes and sizes. Anal Chem, 2012; 84:1702-7.

Mittal AK, Chisti Y, Banerjee UC. Synthesis of metallic nanoparticles using plant extracts. Biotechnol. Adv, 2013; 31:346-56. Nadagouda MN, Varma RS. Green synthesis of silver and palladium nanoparticles at room temperature using coffee and tea extract. Green Chem, 2008; 10:859-62.

Pal S, Tak YK, Song JM. Does the antibacterial activity of silver nanoparticles depend on the shape of the nanoparticle? A study of the gram-negative bacterium Escherichia coli. Appl Environ Microbiol, 2007; 73:1712-20.

Pirtarighat S, Ghannadnia M, Baghshahi S. Green synthesis of silver nanoparticles using the plant extract of Salvia spinosa grown in vitro and their antibacterial activity assessment. J Nanostruct Chem, 2019; 9:1-9.

Roychoudhury P, Gopal PK, Paul S, Pal R. Cyanobacteria assisted biosynthesis of silver nanoparticles - a potential antileukemic agent. J Appl Phycol, 2016; 28:3387-94.

Sharma A, Sharma S, Sharma K, Chetri SP, Vashishtha A, Singh P, Kumar R, Rathi B, Agrawal V. Algae as crucial organisms in advancing nanotechnology: a systematic review. J Appl Phycol, 2016; 28:1759-74.

Smith BC. Infrared spectral interpretation: a systematic approach. CRC Press, Boca Raton, FL, 2018. 
Sönnichsen C, Franzl T, Wilk T, Von Plessen G, Feldmann J. Plasmon resonances in large noble-metal clusters. New J Phys, 2002; 4:93.

Srinivasulu B, Prakasham RS, Jetty A, Srinivas S, Ellaiah P, Ramakrishna SV. Neomycin production with free and immobilized cells of Streptomyces marinensis in an airlift reactor. Process Biochem, 2002; 38:593-8.

Sudha SS, Rajamanickam K, Rengaramanujam J. Microalgae mediated synthesis of silver nanoparticles and their antibacterial activity against pathogenic bacteria. Ind J Exp Biol, 2013; 52:393-9.

Sun T, Zhang YS, Pang B, Hyun DC, Yang M, Xia Y. Engineered nanoparticles for drug delivery in cancer therapy. Angew Chem Int Ed, 2014; 53:12320-64.

Swaminathanályer K. Biogenic production of palladium nanocrystals using microalgae and their immobilization on chitosan nanofibers for catalytic applications. RSC Adv, 2013; 3:1009-12.

Tolosa L, Donato MT, Gómez-Lechón MJ. General cytotoxicity assessment by means of the MTT assay. In: Protocols in In vitro hepatocyte research. Humana Press, New York, NY, pp 333-48, 2015.

Tsibakhashvili NY, Kirkesali EI, Pataraya DT, Gurielidze MA, Kalabegishvili TL, Gvarjaladze DN, Tsertsvadze GI, Frontasyeva MV, Zinicovscaia II, Wakstein MS, Khakhanov SN. Microbial synthesis of silver nanoparticles by Streptomyces glaucus and Spirulina platensis. Adv Sci Lett, 2011; 4:3408-17.
Van Meerloo J, Kaspers GJ, Cloos J. Cell sensitivity assays: the MTT assay. In: Cancer cell culture. Humana Press, Totowa, NJ, pp 237-45, 2011.

Yang H, Yang S, Kong J, Dong A, Yu S. Obtaining information about protein secondary structures in aqueous solution using Fourier transform IR spectroscopy. Nat Protoc, 2015; 10(3):382.

How to cite this article:

Kuraganti GS, Edla S, Dasari T, Reddy M. Characterization, in vitro cytotoxic and antibacterial exploitation of green synthesized freshwater cyanobacterial silver nanoparticles. J Appl Pharm Sci, 2020; 10(09):088-098. 